\title{
Тенденції та перспективи розвитку агропромислового сектору регіонів України
}

\section{Trends and Prospects for the Development of the Agro-Industrial Sector of the Regions of Ukraine}

\section{Руслан Скриньковський ${ }^{1}$, Оксана Процевят ${ }^{2}$, Христина Кайдрович ${ }^{1}$, Юрій Тиркало ${ }^{3}$, Святослав Князь 4 \\ Ruslan Skrynkovskyy, Oksana Protseviat, Khrystyna Kaydrovych, Yuriy Tyrkalo, Sviatoslav Kniaz}

\author{
${ }^{1}$ Lviv University of Business and Law \\ 99 Kulparkivska Street, Lviv, 79021, Ukraine \\ 2 State Institution "M. I. Dolishniy Institute of Regional Research of the NAS of Ukraine" \\ 4 Kozelnytska Street, Lviv, 79026, Ukraine \\ ${ }^{3}$ Non-Governmental Organization "Pan-Ukrainian Anti-Corruption Center" \\ 100/76 Shyroka Street, Lviv, 79052, Ukraine \\ ${ }^{4}$ Lviv Polytechnic National University \\ 12 Stepana Bandery Street, Lviv, 79013, Ukraine
}

\section{DOI: $10.22178 /$ pos.69-11}

JEL Classification:

L60, 013, 018

Received 20.03.2021

Accepted 26.04.2021

Published online 30.04.2021

Corresponding Author:

Oksana Protseviat

oksanayakhymetc@i.ua

(C) 2021 The Authors. This article is licensed under a

Creative Commons

Attribution 4.0 License
Анотація. Забезпечення розвитку агропромислового сектору як на загальнодержавному, так і на регіональному рівнях, виступає пріоритетним завдання інтеграції України не тільки у європейський, але і у глобальний економічний простір. Метою статті $€$ дослідження тенденцій та перспектив розвитку агропромислового сектору регіонів України. У процесі дослідження використано методи теоретичного аналізу, синтезу, спостереження, опису, таблично-графічний, кореляційного аналізу. За результатами дослідження встановлено скорочення частки сектору сільського, лісового та рибного господарства у структурі валового внутрішнього продукту України в період 20152019 років із 12,06 \% у 2015 році до 8,97 \% у 2019 році. Визначено нестабільну динаміку індексу сільського господарства в України протягом 2015-2020 років, де у 2019-2020 роках зниження фізичного обсягу виробництва продукції сільського господарства господарствами усіх категорій становило 6,8 та 12,9 відносних пункти у порівнянні з попередніми роками. Виявлено зростаючу динаміку продуктивності праці на підприємствах, що здійснюють сільськогосподарську діяльність, в період 2015-2019 років, за винятком 2017 року, коли відбулося незначне зниження цього показника на 1,3 \% у порівнянні із 2016 роком. Результати проведеного кореляційного аналізу для визначення взаємозв'язку між ключовими змінними, що характеризують розвиток агропромислового сектору регіонів України, засвідчили, що серед досліджуваних регіонів України дуже високу та високу пряму кореляційну залежність продемонстрували 9-ть регіонів України, серед яких лідером була Львівська область. Запропонований підхід до застосування кореляційного аналізу між обсягом виробленої продукції та витратами усіх підприємств на виробництво продукції (робіт, послуг) можна застосовувати для інших видів економічної діяльності. Перспективи розвитку агропромислового сектору регіонів України вбачаються у такому: 1) створенні спеціальних інтеграційних бізнес-мереж через реалізацію механізмів взаємодії; 2) підтримці здійснення на належному рівні експортних операцій та розвитку власне інфраструктури підтримки експорту, зокрема на рівні регіонів; 3) налагодженні співпраці між потенційними виробниками сировинних ресурсів та переробниками, ефективному використанні виробничих потужностей та інноваційному виробництві продукції агропромислового комплексу (АПК) із застосуванням на цій основі технологічних 
нововведень; 4) ефективному використанні та нарощуванні ресурсного потенціалу, забезпеченні економічної стабільності суб'єктів господарювання АПК; 5) державній підтримці та стимулюванні сфери АПК; 6) реформуванні науково-технічної сфери АПК.

Ключові слова: агропромислова продукція; виробництво; інновації; експорт; агропромисловий бізнес.

Abstract. Ensuring the development of the agro-industrial sector at both the national and regional levels is a priority for Ukraine's integration not only into the European but also into the global economic space. The purpose of the article is to study the trends and prospects for the development of the agro-industrial sector of the regions of Ukraine. In the research process, the methods of theoretical analysis, synthesis, observation, description, tabular-graphic, correlation analysis were used. According to the study results, the reduction of the share of agriculture, forestry and fisheries sector in the structure of the gross domestic product of Ukraine in the period 2015-2019 from $12.06 \%$ in 2015 to $8.97 \%$ in 2019 was established. The unstable dynamics of the agricultural index in Ukraine during 2015-2020 was determined, wherein 2019-2020, the decrease in the physical volume of agricultural production by farms of all categories was 6.8 and 12.9 relative points compared to previous years. There was revealed the growing dynamics of labour productivity at enterprises engaged in agricultural activities in 2015-2019, except for the year 2017, when there was a slight decrease in this indicator by $1.3 \%$, compared to 2016 . The results of the correlation analysis, aimed at determining the relationship between the key variables that characterize the development of the agro-industrial sector of Ukraine, showed that among the studied regions of Ukraine, a very high and high direct correlation was demonstrated by nine regions of Ukraine, among which the Lviv region became the leader. The proposed approach to applying correlation analysis between the volume of output and the expenses of all enterprises for the production (work, services) can be applied to other types of economic activity.

Prospects for the development of the agro-industrial sector of the regions of Ukraine are seen in the following: 1) the creation of unique integration business networks through the implementation of cooperation mechanisms; 2) support for the implementation of export operations at the appropriate level and the development of the existing export support infrastructure, in particular at the regional level; 3) establishing cooperation between potential producers of raw materials and processors, efficient use of production capacity and innovative production of agro-industrial complex (AIC) with the use of technological innovations on this basis; 4) effective use and increase of resource potential, ensuring the economic stability of agro-industrial entities; 5) state support and stimulation of the agro-industrial complex; 6) reforming the scientific and technical sphere of the agro-industrial complex.

Keywords: agro-industrial products; production; innovations; export; agro-industrial business.

\section{ВСТУП}

Одним із пріоритетних завдань інтеграції України (не тільки у європейський, але і у глобальний економічний простір) $є$ забезпечення розвитку агропромислового сектору як на загальнодержавному, так і на регіональному рівнях. Україна, займаючи територію у 60,3 млн. га, що становить близько $6 \%$ площі $\epsilon_{\mathrm{B}-}$ ропи, посідає перше місце у світі за орною площею у 33,5 млн. га. Такі обставини, насамперед, склалися завдяки сприятливим природним умовам і наявності значних резервів природних ресурсів. Водночас слід відмітити, що в Україні, зважаючи на нестабільні темпи розвитку агропромислового сектору, не до кінця використовується наявний природноресурсний потенціал. Тому, враховуючи вищезазначене, актуальним на сьогодні залишається питання щодо визначення основних засад розвитку агропромислового сектору на макро- та мезорівнях.

Аналіз останніх досліджень і публікацій свідчить про те, що останнім часом все більше зростає увага науковців до аспектів розвитку 
аграрної сфери, зарубіжного досвіду економіки аграрного сектору тощо.

Так, досліджуючи розвиток агропромислового комплексу (далі - АПК) України, П. Г. Іжевський [1] наголошує, що ключовою перспективою покращення динаміки розвитку АПК стане застосування на підприємствах цього виду економічної діяльності спеціальних інтеграційних бізнес-мереж через реалізацію механізмів взаємодії, внаслідок чого відбуватиметься адаптація до проблем в контексті пошуку шляхів їх вирішення. Це, своєю чергою, повинно позитивно відобразитися на результатах діяльності підприємств АПК, дозволить підвищити їх конкурентоспроможність і експортний потенціал продукції АПК.

Разом $з$ тим, I. М. Титарчук [2] дотримується думки, що розвиток агропромислового сектору (в контексті підтримки з боку держави та суб'єктів господарювання) повинен забезпечуватись через підтримку здійснення (на належному рівні) експортних операцій, враховуючи їх здешевлення, та через розвиток інфраструктури підтримки експорту, зокрема на рівні регіонів. При цьому науковцем пропонується (як напрям державної підтримки) забезпечити ефективне фінансування окремих витрат, що становлять собівартість продукції АПК.

Фахівець О. В. Перепелюкова [3], за результатами вивчення ризиків агропромислового сектору регіонів України у системі міжнародного бізнесу, стверджує, що основними напрямками розвитку сектору АПК виступатимуть: 1) зниження рівня невизначеності суб'єктів господарювання стосовно постачання і збуту продукції АПК; 2) налагодження співпраці між потенційними виробниками сировинних ресурсів та переробниками; 3) ефективне використання виробничих потужностей; 4) інноваційне виробництво продукції АПК із застосуванням на цій основі технологічних нововведень тощо.

Вчені О. О. Корогодова і В. Ф. Семенов [4] розглядають тенденції просторового розвитку АПК в контексті впливу транснаціоналізації. У підсумку науковці наголошують, що для посилення транснаціоналізації агропромислового бізнесу України потрібно, насамперед, ефективно використовувати i нарощувати ресурсний потенціал, забезпечити економічну стабільність суб'єктів господарювання
АПК, а також підвищити рівень ефективності використання виробничих потужностей.

Вчені С. Я. Берсуцька та С. О. Колесников [5] досліджують проблематику розвитку агропромислового комплексу України в умовах інтеграції до системи європейського економічного простору. Узагальнюючи дослідження, науковці виділяють такі перспективні напрямки забезпечення розвитку агропромислового бізнесу України: 1) гармонізація законодавства України, яким регулюються засади розвитку АПК, до законодавства Європейського Союзу; 2) постійне контролювання діяльності суб'єктів господарювання АПК і сфери АПК в цілому відповідно до ініціативи та підтримки Європейської комісії; 3) закріплення рівня харчової безпеки Європи як еталону і дотримання такого рівня українськими виробниками продукції АПК; 4) розроблення та постійне удосконалення української продукції АПК не тільки на європейських, але і на світових ринках; 5) державна підтримка та стимулювання сфери АПК як на рівні країни, так і на рівні регіонів чи мікрорівні господарювання.

Вчені М. М. Берест та М. О. Дудка [6] у своєму дослідженні оцінюють рівень стійкості агропромислового комплексу на макрорівні, виходячи із трьох складових: економічної, соціальної та екологічної. Підсумовуючи дослідження, науковці зауважують висхідний рівень стійкості розвитку агропромислового комплексу країни, при чому особливий наголос робиться на екологічній складовій, оскільки на сьогодні слід поглиблено розробляти та впроваджувати механізми пристосування виробництва продукції АПК до несприятливих умов, а також знижувати вплив самого виробництва на навколишнє середовище.

Також існує позиція щодо забезпечення розвитку АПК країни, виходячи із впливу на цей процес інновацій. В контексті цього, О. П. Радченко [7] зазначає, що сьогодні потрібно першочергово реформувати науковотехнічну сферу АПК. Це дозволить підвищити конкурентоспроможність виробництва АПК та продавати не сировинну продукцію, а продукцію із високою часткою доданої вартості.

Окрім досліджень науковців, перспективи розвитку агропромислового сектору в Україні та іiі регіонах визначені і окреслені чинним Законом України "Про систему інженернотехнічного забезпечення агропромислового 
комплексу України” від 05.10.2006 р. № 229-V [8]. Так, у законодавчому документі встановлено економічні, правові і організаційні аспекти формування та функціонування цілісної системи інженерно-технічного забезпечення агропромислового сектору, а також цим документом регулюються зв'язки у напрямку технічного і технологічного обслуговування системи інженерно-технічного забезпечення агропромислового сектору та посилюється розвиток економічних умов, що $\epsilon$ необхідними для створення, виробництва, випробування, реалізації, використання і обслуговування ряду технічних засобів для сфери агропромислового виробництва.

Опираючись на вищенаведене, а також враховуючи думку керівників аграрних підприємств і спеціалістів у сфері економіки аграрного сектору, з'ясовано, що питання розвитку агропромислового сектору регіонів України 3 позиції практичних аспектів, виходячи із реалій сьогодення, залишаються недостатньо вивченими та розкритими, і потребують додаткового дослідження.

Метою статті є дослідження тенденцій та перспектив розвитку агропромислового сектору регіонів України. Досягнення окресленої мети і її реалізація зумовила необхідність вирішення таких наукових завдань: 1) проаналізувати динаміку валового внутрішнього продукту (далі - ВВП) України та частку сектору сільського, лісового та рибного господарства у структурі ВВП України; 2) дослідити основні індикатори розвитку агропромислового сектору України; 3) провести кореляційний аналіз для визначення взаємозв'язку між ключовими змінними, що характеризують розвиток агропромислового сектору регіонів України.

У процесі дослідження (при досягненні загальної мети та основних завдань роботи - обгрунтуванні положень, висновків і пошуку нових рішень для вирішення проблеми) використано такі методи: а) метод теоретичного аналізу, метод синтезу, метод спостереження, метод опису - для розкриття теоретико-практичних аспектів розвитку агропромислового сектору регіонів України; б) таблично-графічний метод - для представлення динаміки основних індикаторів розвитку агропромислового сектору регіонів України; в) метод кореляційного аналізу - для встановлення взаємозв'язку між обсягом виробленої продукції сільського господарства у підприємствах та витратами усіх підприємств на виробництво продукції (робіт, послуг) сільського господарства як в Україні загалом, так і у регіональному розрізі (при цьому визначення ступеня взаємозв'язку між досліджуваними змінними здійснено через застосування шкали Чеддока).

Основу інформаційної бази дослідження становили такі індикатори, як [9, 10]: 1) ВВП, млн. грн.; 2) обсяг продукції сільського, лісового та рибного господарства, млн. грн.; 3) індекс сільського господарства в Україні (у постійних цінах 2016 року, \% до попереднього року); 4) продуктивність праці на підприємствах, що здійснюють сільськогосподарську діяльність (на 1-го зайнятого працівника у постійних цінах 2016 року, тис. грн.); 5) обсяг виробленої продукції сільського господарства у підприємствах, млн. грн.; 6) витрати усіх підприємств на виробництво продукції (робіт, послуг) сільського господарства, млн. грн.

\section{РЕЗУЛЬТАТИ ДОСЛІДЖЕННЯ}

Аналіз динаміки ВВП України засвідчив тенденційне зростання головного індикатора національної економіки в досліджуваний період. Однак, темпи зростання ВВП України протягом 2018-2020 років сповільнювались. Так, за 2020 рік зростання ВВП становило лише $5,4 \%$, порівняно із попереднім роком, та було на половину нижчим, ніж зростання за 2019 рік (рисунок 1).

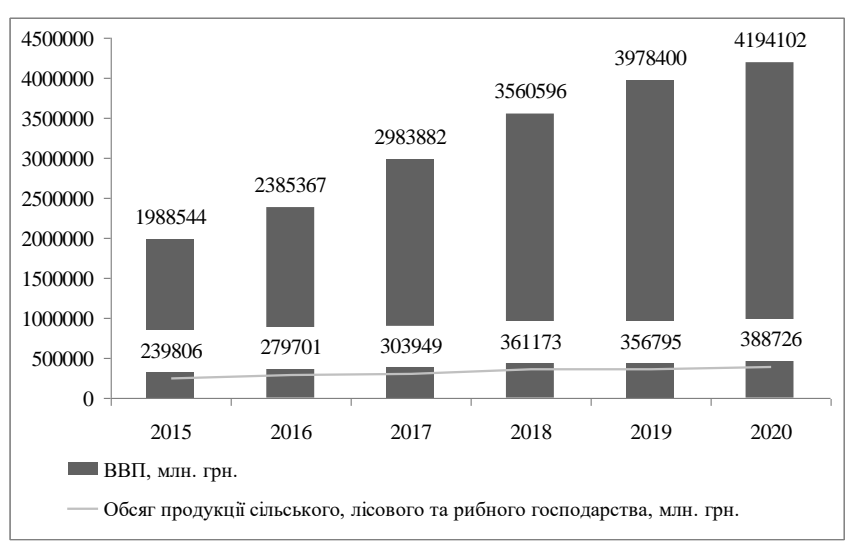

Рисунок 1 - Динаміка ВВП та обсягу продукції сільського, лісового та рибного господарства [9]

Уповільнення темпів зростання національної економіки негативно позначається на тенде- 
нціях розвитку видів економічної діяльності, зокрема сектору сільського, лісового та рибного господарства, оскільки частка цього виду економічної діяльності у структурі ВВП України в період 2015-2019 років поступово скорочується - із 12,06 \% у 2015 році до 8,97 \% у 2019 році. За 2020 рік відбулося незначне покращення, оскільки питома вага сільського, лісового та рибного господарства у структурі ВВП зросла на 0,30 \% до 9,27 \%.

В період 2015-2020 років динаміка обсягу продукції сільського, лісового та рибного господарства мала зростаючий характер (за винятком 2019 року), однак темпи зростання були нестабільними. Найвищий темп зрос- тання обсягу відбувся у 2018 році (на $18,83 \%$, порівняно з попереднім роком), а у 2020 році темп зростання становив лише 8,95 \% після падіння у 2019 році - на 1,21 \%.

Індекс сільського господарства в України протягом 2015-2020 років продемонстрував нестабільну динаміку. Відтак, після значного падіння у 2017 році (на 8,5 відносних пункти (далі - в. п.), порівняно із 2016 роком) у 2018 році відбулось зростання фізичного обсягу виробництва продукції сільського господарства господарствами усіх категорій на 10,4 в. п., а у 2019-2020 роках - знову зниження на 6,8 та 12,9 в. п., у порівнянні 3 попередніми роками (таблиця 1).

Таблиця 1 - Індекси сільського господарства в Україні, у постійних цінах 2016 року, \% до попереднього року (на основі даних $[9,10])$

\begin{tabular}{|c|c|c|c|c|c|c|}
\hline Продукція сільського господарства & 2015 & 2016 & 2017 & 2018 & 2019 & $2020^{*}$ \\
\hline \multicolumn{7}{|l|}{ Господарства усіх категорій } \\
\hline Загалом & 95,2 & 106,3 & 97,8 & 108,2 & 101,4 & 88,5 \\
\hline \multicolumn{7}{|l|}{3 неї: } \\
\hline продукція рослинництва & 94,8 & 109,1 & 97,1 & 110,2 & 101,8 & 86,1 \\
\hline продукція тваринництва & 96,4 & 97,3 & 100,2 & 101,2 & 100,2 & 97,4 \\
\hline \multicolumn{7}{|l|}{ Підприємства } \\
\hline Загалом & 94,8 & 109,7 & 97,0 & 112,0 & 102,7 & 86,0 \\
\hline \multicolumn{7}{|l|}{3 неї: } \\
\hline продукція рослинництва & 94,5 & 112,4 & 96,2 & 113,6 & 102,5 & 83,5 \\
\hline продукція тваринництва & 96,5 & 97,5 & 101,0 & 104,5 & 103,8 & 99,1 \\
\hline \multicolumn{7}{|l|}{ Господарства населення } \\
\hline Загалом & 95,8 & 100,9 & 99,3 & 101,7 & 99,1 & 93,2 \\
\hline \multicolumn{7}{|l|}{3 неї: } \\
\hline продукція рослинництва & 95,5 & 102,8 & 99,1 & 103,3 & 100,2 & 92,2 \\
\hline продукція тваринництва & 96,3 & 97,2 & 99,6 & 98,1 & 96,7 & 95,5 \\
\hline
\end{tabular}

Примітка: * - дані попередні

У розрізі продукції сільського господарства нестабільну динаміку демонстрували як індекс продукції рослинництва, так і індекс продукції тваринництва, при чому найбільш суттєвими були зміни фізичного обсягу виробництва продукції рослинництва. Так, після значного зниження індексу продукції рослинництва у 2017 році на 12,0 в. п., у 2018 році відбулося його збільшення на 13,1 в. п., порівняно із попереднім роком, а у 2019-2020 роках - знову зниження на 8,4 та 15,7 в. п. відповідно у порівнянні із попередніми роками. Натомість індекс продукції тваринництва демонстрував падіння у 2019-2020 роках на 1,0 та 2,8 в. п. відповідно у порівнянні із попередніми роками. Щодо виробників продукції, то більш нестабільною є динаміка фізичного обсягу виробництва продукції рослинництва підприємствами (протягом 2019-2020 років відбулося значне падіння індексу продукції рослинництва, що вироблена підприємствами, на 11,1 та 19,0 в. п. відповідно, порівняно із попередніми роками), ніж динаміка фізичного обсягу виробництва продукції рослинництва господарствами населення (падіння індексу продукції рослинництва, що вироблена господарствами населення, за 20192020 роки становило лише 3,1 та 8,0 в. п. відповідно у порівнянні із попередніми роками). Водночас динаміка індексів продукції тваринництва, що вироблена як підприємствами, так і господарствами населення, також $\epsilon$ нестабільною, однак темпи зниження фізичного обсягу виробництва продукції тварин- 
ництва підприємствами за період 2019-2020 років становили лише 0,7 та 4,7 в. п. відповідно, а фізичного обсягу виробництва продукції тваринництва господарствами населення 1,4 та 1,2 в. п. відповідно у порівнянні із попередніми роками.
Упродовж 2015-2019 років динаміка продуктивності праці на підприємствах, що здійснюють сільськогосподарську діяльність, була зростаючою, за винятком 2017 року, коли відбулося незначне зниження цього показника на 1,3 \% у порівнянні із 2016 роком (таблиця 2).

Таблиця 2 - Продуктивність праці на підприємствах, що здійснюють сільськогосподарську діяльність (на 1-го зайнятого працівника у постійних цінах 2016 року, тис. грн.) [9]

\begin{tabular}{|l|c|c|c|c|c|r|}
\hline \multicolumn{1}{|c|}{ Сільськогосподарське виробництво } & 2015 & 2016 & 2017 & 2018 & 2019 & 2020 \\
\hline Загалом & 624,0 & 765,0 & 755,4 & 867,7 & 928,6 & немає даних (н. д.) \\
\hline Виробництво продукції рослинництва & 660,0 & 804,0 & 777,4 & 900,1 & 954,4 & н.д. \\
\hline Виробництво продукції тваринництва & 503,9 & 614,6 & 664,8 & 730,4 & 815,2 & н. д. \\
\hline
\end{tabular}

Протягом аналізованого періоду, незважаючи на нестабільну динаміку індексу продукції тваринництва, продуктивність праці на підприємствах, що виробляють продукцію тваринництва, зростала, причому суттєве збільшення відбулося у 2016 році (на 22,0 \%) та у 2019 році (на 11,6 \%) у порівнянні із попереднім роком. Натомість динаміка продуктивності праці на підприємствах, що виробляють продукцію рослинництва, демонструвала не- значне зниження цього показника у 2017 році на 3,3 \%.

Для дослідження перспектив розвитку агропромислового сектору регіонів Україно проведено кореляційний аналіз між змінною $L$ (обсяг виробленої продукції сільського господарства у підприємствах ) та змінною $S$ (витрати усіх підприємств на виробництво продукції (робіт, послуг) сільського господарства) як в Україні загалом, так і у регіональному розрізі (таблиця 3 ).

Таблиця 3 - Вхідні дані для кореляційного аналізу [9]

\begin{tabular}{|c|c|c|c|c|c|c|c|c|}
\hline \multirow{2}{*}{ Регіон } & \multicolumn{2}{|c|}{2016} & \multicolumn{2}{|c|}{2017} & \multicolumn{2}{|c|}{2018} & \multicolumn{2}{|c|}{2019} \\
\hline & L1 & S1 & L2 & S2 & L3 & S3 & L4 & S4 \\
\hline Україна & 254640,5 & 288499,3 & 249157,0 & 404970,2 & 69408,1 & 442993,4 & 449806,3 & 463271,6 \\
\hline Вінницька & 21319,1 & 23416,7 & 20423,1 & 27946,3 & 22589,5 & 39393,9 & 42411,8 & 37521,6 \\
\hline Волинська & 6558,5 & 6124,4 & 6872,1 & 7655,5 & 7089,2 & 9281,5 & 8664,3 & 9651,7 \\
\hline Дніпропетровська & 15183,4 & 18097,3 & 15255,5 & 22823,4 & 15667,4 & 25491,3 & 29353,2 & 28675,7 \\
\hline Донецька & 7513,1 & 8390,1 & 7681,1 & 9118,0 & 6956,1 & 10460,9 & 13142,7 & 11471,6 \\
\hline Жи & 9406,8 & 6323,1 & 9949,5 & 9149,0 & 11128,7 & 12599,1 & 15807,3 & 14264,9 \\
\hline Зака & 3964,9 & 652,7 & 4021,4 & 843,6 & 4301,2 & 938,9 & 838,9 & 1036,6 \\
\hline Зап & 9928,0 & 1187,4 & 9605,2 & ,9 & 8220,2 & 14879,0 & 8017,5 & 16523,5 \\
\hline Iва1 & 5795,3 & & 6029,3 & & 6108,2 & 6686,5 & 5148,5 & \\
\hline Київська & 15544,7 & 27071,6 & 14881,5 & 31707,0 & 18427,4 & 35885,4 & 30478,6 & 37174,4 \\
\hline Kipo & 12037,5 & 14223,5 & 10369,5 & 17268,2 & 12503,0 & 20058,8 & 24234,4 & 23069,9 \\
\hline Луганська & 4816,3 & 5057,1 & 4527,5 & 7097,6 & 4946,0 & 7970,6 & 9879,7 & 8450,4 \\
\hline Львівська & 9255,4 & 6362,3 & 9820,0 & 8434,5 & 10189,9 & 10413,4 & 11063,3 & 12055,9 \\
\hline Миколаїв & 9714,0 & 11631,8 & 8833,8 & 12536,9 & 9362,7 & 14196,0 & 16798,5 & 15532,7 \\
\hline Одє & 11881,2 & 13478,7 & 11809,7 & 17333,0 & 11943,2 & 21126,8 & 17125,6 & 22569,7 \\
\hline Пол & 17212,6 & 232 & 14316,7 & 271 & 17747,4 & 29257,1 & 30797,0 & 29724,1 \\
\hline$\overline{\mathrm{PiBH}}$ & 6723,2 & & 70 & 7,5 & 7237,4 & 79 & $\begin{array}{l}7653,3 \\
\end{array}$ & 6980,4 \\
\hline Сум & 192,5 & 117 & 10193,5 & 150 & 11362,2 & 193 & 23516,1 & 20218,5 \\
\hline Тернопіл & 8523,8 & 8600,2 & 9470,8 & 11690,0 & 9836,6 & 14618,4 & 15725,2 & 15000,4 \\
\hline Харківська & 15647,8 & 16493,1 & 14100,4 & 19414,8 & 14949,1 & 21829,4 & 25195,0 & 24122,7 \\
\hline Херсонська & 11232,2 & 9821,7 & 11182,8 & 12289,5 & 11243,9 & 14736,7 & 17389,1 & 15602,3 \\
\hline Хмел & 12548,6 & 12526,6 & 14056,5 & 18049,2 & 14426,4 & 21137,3 & 25784,8 & 22085,6 \\
\hline Черг & 14983,7 & 20855,2 & 13262,2 & 28381,1 & 16284,2 & 37231,6 & 32673,5 & 32622,1 \\
\hline Чep & 4285,7 & 200 & 4513,0 & 2194,5 & 4750,1 & 2925,3 & 2731,9 & 2930,1 \\
\hline Чернігівська & 10372,2 & 14541,1 & 10923,9 & 48147,7 & 12138,1 & 24296,2 & 25376,1 & 26575,1 \\
\hline
\end{tabular}


За результатами проведеного обчислення одержано певні значення коефіцієнта кореляції та встановлено взаємозв'язок між залежними змінними (при цьому визначення ступеня взаємозв'язку між досліджуваними змінними здійснено через застосування шкали Чеддока) (таблиця 4).

Таблиця 4 - Результати кореляційного аналізу

\begin{tabular}{|l|l|l|}
\hline Регіон & \multicolumn{2}{|l|}{ Коефіцієнт кореляції } \\
\hline Кореляція слабка & \multicolumn{2}{|l|}{} \\
\hline Чернігівська & Обернений зв'язок & $-0,0775$ \\
\hline Кореляція помірна & \multicolumn{2}{|l|}{} \\
\hline Івано-Франківська & \multirow{2}{*}{ Обернений зв'язок } & $-0,4860$ \\
\hline Чернівецька & & $-0,3988$ \\
\hline Черкаська & Прямий зв'язок & 0,3327 \\
\hline
\end{tabular}

Кореляція середня

\begin{tabular}{|l|l|l|}
\hline Закарпатська & Обернений зв'язок & $-0,6284$ \\
\hline
\end{tabular}

\begin{tabular}{|c|c|c|}
\hline & \multirow{12}{*}{ Прямий зв’язок } & \\
\hline Полтавська & & 0,5225 \\
\hline Вінницька & & 0,5306 \\
\hline Україна & & 0,5740 \\
\hline Луганська & & 0,5839 \\
\hline Запорізька & & 0,6305 \\
\hline Херсонська & & 0,6386 \\
\hline Одеська & & 0,6512 \\
\hline Хмельницька & & 0,6659 \\
\hline Сумська & & 0,6721 \\
\hline Тернопільська & & 0,6925 \\
\hline Харківська & & 0,6991 \\
\hline
\end{tabular}

Кореляція висока

\begin{tabular}{|c|c|c|}
\hline Донецька & \multirow{8}{*}{ Прямий зв’язок } & 0,7210 \\
\hline Київська & & 0,7258 \\
\hline Рівненська & & 0,7448 \\
\hline Дніпропетровська & & 0,7478 \\
\hline Волинська & & 0,7729 \\
\hline Миколаївська & & 0,7732 \\
\hline Кіровоградська & & 0,7857 \\
\hline Житомирська & & 0,8460 \\
\hline
\end{tabular}

Кореляція дуже висока

\begin{tabular}{|l|l|}
\hline Львівська & Прямий зв'язок \\
\hline
\end{tabular}

0,9772

Вивчення даних таблиці 4 дає підстави відмітити про наявність прямого дуже високого взаємозв'язку між обсягом виробленої продукції сільського господарства у підприємствах та витратами усіх підприємств на виробництво продукції (робіт, послуг) сільського господарства у Львівській області. Натомість у Житомирській, Кіровоградській, Миколаївській, Волинській, Дніпропетровській, Рівненській, Київській та Донецькій областях зв'язок $є$ високим, що свідчить про те, що зростання обсягу виробленої продукції сільського господарства у підприємствах впливає на зростання витрат усіх підприємств на виробництво продукції (робіт, послуг) сільського господарства. В Україні, як і в Харківській, Тернопільській, Сумській, Хмельницькій, Одеській, Херсонській, Запорізькій, Луганській, Вінницькій та Полтавській областях кореляція між обсягом виробленої продукції сільського господарства у підприємствах та витратами усіх підприємств на виробництво продукції (робіт, послуг) сільського господарства $\epsilon$ середньою. Водночас Закарпатська область демонструє також середню кореляцію між аналізованими змінними, однак взаємозв'язок між ними $є$ оберненим, що свідчить про те, що зростання обсягу виробленої продукції сільського господарства у підприємствах впливає на зниження витрат усіх підприємств на виробництво продукції (робіт, послуг) сільського господарства. У Чернігівській області взаємозв'язок між аналізованими змінними є оберненим та слабким, а у Чернівецькій та Івано-Франківській - оберненим та помірним. Своєю чергою, Черкаська область демонструє пряму помірну кореляцію між обсягом виробленої продукції сільського господарства у підприємствах та витратами усіх підприємств на виробництво продукції (робіт, послуг) сільського господарства.

Отже, сьогодні існує пряма дуже висока залежність між аналізованими змінними у Львівській області, натомість у Черкаській області ця залежність $\epsilon$ оберненою та слабкою. В Україні кореляція між обсягом виробленої продукції сільського господарства у підприємствах та витратами усіх підприємств на виробництво продукції (робіт, послуг) сільського господарства) $є$ прямою та середньою.

За результатами проведеного кореляційного аналізу між обсягом виробленої продукції сільського господарства у підприємствах та витратами усіх підприємств на виробництво продукції (робіт, послуг) сільського господарства) як в Україні загалом, так і у регіональному розрізі, можна зробити висновки і визначити ряд перспектив розвитку агропромислового сектору регіонів України, зокрема вони вбачаються у такому: 1) створенні спеціальних інтеграційних бізнес-мереж через реалізацію механізмів взаємодії [1]; 2) підтримці здійснення на належному рівні експортних операцій та розвитку власне інфраструктури підтримки експорту, зокрема на рівні регіонів [2]; 3) налагодженні співпраці між потенційними виробниками сировинних ре- 
сурсів та переробниками, ефективному використанні виробничих потужностей та інноваційному виробництві продукції АПК із застосуванням на цій основі технологічних нововведень [3]; 4) ефективному використанні та нарощуванні ресурсного потенціалу, забезпеченні економічної стабільності суб'єктів господарювання АПК $[4,11,12,13]$; 5) державній підтримці та стимулюванні сфери АПК $[5,14$, $15,16]$; 6) реформуванні науково-технічної сфери АПК $[7,15,17,18]$.

\section{ВИСНОВКИ}

Дослідження тенденцій та перспектив розвитку агропромислового сектору регіонів України показало:

- скорочення частки сектору сільського, лісового та рибного господарства у структурі ВВП України в період 2015-2019 років із 12,06 \% у 2015 році до 8,97 \% у 2019 році;

- нестабільну динаміку індексу сільського господарства в України протягом 2015-2020 років, де у 2019-2020 роках зниження фізичного обсягу виробництва продукції сільського господарства господарствами усіх категорій становило 6,8 та 12,9 в. п. відповідно у порівнянні з попередніми роками;
- зростаючу динаміку продуктивності праці на підприємствах, що здійснюють сільськогосподарську діяльність в період 2015-2019 років, за винятком 2017 року, коли відбулося незначне зниження цього показника на 1,3 \% у порівнянні із 2016 роком.

Результати проведеного кореляційного аналізу для визначення взаємозв'язку між ключовими змінними, що характеризують розвиток агропромислового сектору регіонів України, засвідчили, що серед досліджуваних регіонів України дуже високу та високу пряму кореляційну залежність продемонстрували 9ть регіонів України, серед яких лідером була Львівська область.

Запропонований підхід до застосування кореляційного аналізу між обсягом виробленої продукції та витратами усіх підприємств на виробництво продукції (робіт, послуг) можна застосовувати для дослідження інших видів економічної діяльності.

Перспективами подальших досліджень у цьому напрямі $\epsilon$ комплексне дослідження розвитку агропромислового сектору як на рівні країни, так і на рівні регіонів в контексті входження у систему європейського та світового економічного простору.

\section{СПИСОК ВИКОРИСТАНИХ ДЖЕРЕЛ / REFERENCES}

1. Izhevskyi, P. H. (2018). Ahropromyslovyi kompleks Ukrainy: suchasnyi stan, tendentsii ta perspektyvy rozvytku [Agro-industrial complex of Ukraine: contemporary state, trends and prospects of development]. Intelekt XXI, 3, 59-64 (in Ukrainian)

[Іжевський, П. Г. (2018). Агропромисловий комплекс України: сучасний стан, тенденції та перспективи розвитку. Інтелект XXI, 3, 59-64].

2. Tytarchuk, I. M. (2020). Analiz roli ahropromyslovoho kompleksu v ekonomitsi krainy: vnutrishnii rozvytok ta zovnishnia torhivlia [The analysis of the role of the agro-industrial sector in economisc: internal development and foreign trade]. Aktualni problemy rozvytku ekonomiky rehionu, 2(16), 84-93. doi: 10.15330/apred.2.16.84-93 (in Ukrainian)

[Титарчук, I. M. (2020). Аналіз ролі агропромислового комплексу в економіці країни: внутрішній розвиток та зовнішня торгівля. Актуальні проблеми розвитку економіки регіону, 2(16), 84-93. doi: 10.15330/apred.2.16.84-93].

3. Perepeliukova, O. V. (2017). Suchasni ryzyky ahropromyslovoho kompleksu rehioniv u konteksti rozvytku mizhnarodnoho biznesu [Modern risks of the agro-industrial complex of regions in the context of international business development]. Ekonomika ta pravo, 3(48), 106-109 (in Ukrainian)

[Перепелюкова, О. В. (2017). Сучасні ризики агропромислового комплексу регіонів у контексті розвитку міжнародного бізнесу. Економіка та право, 3(48), 106-109].

4. Korohodova, O. O., \& Semenov, V. F. (2018). Zasady prostorovoho rozvytku ukrainskoho ahrobiznesu $\mathrm{z}$ urakhuvanniam protsesiv transnatsionalizatsii [Bases of spatial development of Ukrainian 
agriculture in focus of transnationalization processes]. Ekonomichnyi visnyk Natsionalnoho tekhnichnoho universytetu Ukrainy "Kyivskyi politekhnichnyi instytut", 15, 165-172 (in Ukrainian) [Корогодова, 0. О., \& Семенов, В. Ф. (2018). Засади просторового розвитку українського агробізнесу з урахуванням процесів транснаціоналізації. Економічний вісник Національного технічного університету України “Київський політехнічний інститут", 15, 165-172].

5. Bersutska, S. Ya., \& Kolesnykov, S. O. (2019). Potochnyi stan ta perspektyvy rozvytku ahropromyslovoho sektoru Ukrainy v konteksti yevrointehratsii [The current state and prospects of development of Ukraine's agro-industrial sector in the context of European integration]. Ekonomichnyi visnyk Donbasu, 3(57), 115-122. doi: 10.12958/1817-3772-20193(57)-115-122 (in Ukrainian) [Берсуцька, С. Я., \& Колесников, С. О. (2019). Поточний стан та перспективи розвитку агропромислового сектору України в контексті євроінтеграції. Економічний вісник Донбасу, 3(57), 115-122. doi: 10.12958/1817-3772-2019-3(57)-115-122].

6. Berest, M. M., \& Dudka, M. O. (2017). Otsinka rivnia stiikosti rozvytku ahropromyslovoho sektoru ekonomiky Ukrainy [Assessing the level of the agribusiness sustainable development in the economy of Ukraine]. Ekonomika rozvytku, 4(84), 27-37 (in Ukrainian) [Берест, М. М., \& Дудка, М. О. (2017). Оцінка рівня стійкості розвитку агропромислового сектору економіки України. Економіка розвитку, 4(84), 27-37].

7. Radchenko, O. P. (2019). Innovatsiini aspekty rozvytku ahropromyslovoho kompleksu v umovakh hlobalizatsii [Innovative aspects of agricultural complex development in globalization]. Ekonomika. Finansy. Pravo, 10/1, 19-23 (in Ukrainian) [Радченко, О. П. (2019). Інноваційні аспекти розвитку агропромислового комплексу в умовах глобалізації. Економіка. Фінанси. Право, 10/1, 19-23].

8. Pro systemu inzhenerno-tekhnichnoho zabezpechennia ahropromyslovoho kompleksu Ukrainy [About the system of engineering and technical support of the agro-industrial complex of Ukraine] (Ukraine), 05.10.2006, No 229-V. Retrieved March 1, 2021, from https://zakon.rada.gov.ua/laws/show/229-16\#Text (in Ukrainian) [Про систему інженерно-технічного забезпечення агропромислового комплексу України (Україна), 05.10.2006, № 229-V. Актуально на 01.03.2021. URL: https://zakon.rada.gov.ua/laws/show/229-16\#Text].

9. Derzhavna sluzhba statystyky Ukrainy. (2021). Statystychna informatsiia [Statistical information]. Retrieved March 1, 2021, from http://www.ukrstat.gov.ua (in Ukrainian) [Державна служба статистики України. (2021). Статистична інформація. Актуально на 01.03.2021. URL: http://www.ukrstat.gov.ua].

10. Informatsiino-analitychnyi portal APK Ukrainy. (2021). Reitynhy rehioniv za pidsumkamy diialnosti $A P K$ [Ratings of regions based on the results of the agro-industrial complex]. Retrieved March 1, 2021, from https://agro.me.gov.ua/ua/investoram/monitoring-stanu-apk/rejting-regioniv-zapidsumkami-diyalnosti-apk (in Ukrainian)

[Інформаційно-аналітичний портал АПК України. (2021). Рейтинги регіонів за підсумками діяльності АПК. Актуально на 01.03.2021. URL:

https://agro.me.gov.ua/ua/investoram/monitoring-stanu-apk/rejting-regioniv-za-pidsumkamidiyalnosti-apk].

11. Sumets, A., Kniaz, S., Heorhiadi, N., Farat, O., Skrynkovskyy, R., \& Martyniuk, V. (2021). Methodical approach to the selection of options for ensuring competitiveness of enterprises in the system of development of agricultural clusters. Agricultural and Resource Economics: International Scientific E-Journal, 7(1)192-210. doi: 10.51599/are.2021.07.01.10

12. Sumets, A., Serbov, M., Skrynkovskyy, R., Faldyna, V., \& Satusheva, K. (2020). Analysis of influencing factors on the development of agricultural enterprises based on e-commerce technologies. Agricultural and Resource Economics: International Scientific E-Journal, 6(4), 211-231. doi: 10.51599/are.2020.06.04.11 
13. Pavlenchyk, N., Horbonos, F., Pavlenchyk, A., \& Skrynkovskyy, R. (2020). Paradigm of the functional approach to manifestations of risk in performance of enterprises under market conditions. Ekonomika APK, 308(6), 98-113. doi: 10.32317/2221-1055.202006098

14. Derzhavna tsilova prohrama rozvytku ahrarnoho sektoru ekonomiky na period do 2022 roku [State target program for the development of the agricultural sector of the economy until 2022] (Ukraine), 30.12.2015, No 1437-p. Retrieved March 1, 2021, from https://zakon.rada.gov.ua/laws/show/1437-2015-p (in Ukrainian) [Державна цільова програма розвитку аграрного сектору економіки на період до 2022 року (Україна), 30.12.2015, № 1437-р. Актуально на 01.03.2021. URL: https://zakon.rada.gov.ua/laws/show/1437-2015-p].

15. Betlii, M. H. (2006). Ahrarnyi sektor Ukrainy na shliakhu do yevrointehratsii [Ukraine's agricultural sector on the path to European integration]. Uzhhorod: IVA (in Ukrainian)

[Бетлій, М. Г. (2006). Аграрний сектор України на шляху до євроінтеграції. Ужгород: IBA].

16. Kyryliuk, Ye. M. (2013). Ahrarnyi rynok v umovakh transformatsii ekonomichnykh system

[Agricultural market in the conditions of transformation of economic systems]. Kyiv: KNEU (in Ukrainian)

[Кирилюк, Є. М. (2013). Аграрний ринок в умовах трансформації економічних систем. Київ: KHEУ].

17. Sytnyk, V. P. (2002). Transformatsiia APK Ukrainy v rynkovi umovy [Transformation of the agroindustrial complex of Ukraine into market conditions]. Kyiv: Instytut ahrarnoi ekonomiky UAAN (in Ukrainian)

[Ситник, В. П. (2002). Трансформація АПК України в ринкові умови. Київ: Інститут аграрної економіки УААН].

18. Mostovyi, H. I. (2002). Ahrobiznes: derzhavne rehuliuvannia [Agribusiness: government regulation]. Kharkiv: Osnova (in Ukrainian)

[Мостовий, Г. І. (2002). Агробізнес: державне регулювання. Харків: Основа]. 